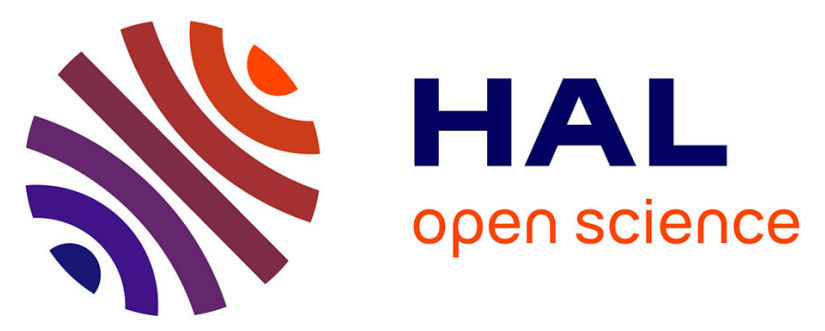

\title{
Effect of hydraulic retention time on a continuous biohydrogen production in a packed bed biofilm reactor with recirculation flow of the liquid phase
}

Wirginia Tomczak, Jean-Henry Ferrasse, Marie-Thérèse Giudici-Orticoni, Audrey Soric

\section{To cite this version:}

Wirginia Tomczak, Jean-Henry Ferrasse, Marie-Thérèse Giudici-Orticoni, Audrey Soric. Effect of hydraulic retention time on a continuous biohydrogen production in a packed bed biofilm reactor with recirculation flow of the liquid phase. International Journal of Hydrogen Energy, 2018, 43 (41), pp.18883-18895. 10.1016/j.ijhydene.2018.08.094 . hal-02116035

\section{HAL Id: hal-02116035 \\ https://hal-amu.archives-ouvertes.fr/hal-02116035}

Submitted on 30 Apr 2019

HAL is a multi-disciplinary open access archive for the deposit and dissemination of scientific research documents, whether they are published or not. The documents may come from teaching and research institutions in France or abroad, or from public or private research centers.
L'archive ouverte pluridisciplinaire HAL, est destinée au dépôt et à la diffusion de documents scientifiques de niveau recherche, publiés ou non, émanant des établissements d'enseignement et de recherche français ou étrangers, des laboratoires publics ou privés. 


\title{
Effect of hydraulic retention time on a continuous \\ biohydrogen production in a packed bed biofilm reactor with recirculation flow of the liquid phase
}

\author{
Wirginia Tomczak ${ }^{a}$, Jean-Henry Ferrasse ${ }^{a}$, \\ Marie-Thérèse Giudici-Orticoni ${ }^{b}$, Audrey Soric ${ }^{a, *}$ \\ a Aix Marseille Univ, CNRS, Centrale Marseille, M2P2, Marseille, France \\ ${ }^{\mathrm{b}}$ CNRS, Aix Marseille Univ, BIP, Marseille, France
}

\section{A R T I C L E I N F O}

Keywords:

Dark fermentation

Anaerobic packed bed reactor

Mesophilic sludge

Hydraulic retention time

Homoacetogenic bacteria

\begin{abstract}
A B S T R A C T
The present paper reports on results obtained from experiments carried out in a laboratory-scale anaerobic packed bed biofilm reactor (APBR), with recirculation of the liquid phase, for continuously biohydrogen production via dark fermentation. The reactor was filled with Kaldnes ${ }^{\circledR}$ biofilm carrier and inoculated with an anaerobic mesophilic sludge from a urban wastewater treatment plant (WWTP). The APBR was operated at a temperature of $37{ }^{\circ} \mathrm{C}$, without $\mathrm{pH}$ buffering. The effect of theoretical hydraulic retention time (HRT) from 1 to $5 \mathrm{~h}$ on hydrogen yield (HY), hydrogen production rate (HPR), substrate conversion and metabolic pathways was investigated. This study indicates the possibility of enhancing hydrogen production by using APBR with recirculation flow. Among respondents values of HRT the highest average values of $\mathrm{HY}\left(2.35 \mathrm{~mol} \mathrm{H}_{2} / \mathrm{mol}\right.$ substrate) and HPR $\left(0.085 \mathrm{~L} \mathrm{~h}^{-1} \mathrm{~L}^{-1}\right)$ have been obtained at HRT equal to $2 \mathrm{~h}$.
\end{abstract}

\section{Introduction}

Currently, sustainable production of fuels is important due to global demand for energy, uncertainty in the supply of petroleum resources and environmental concerns bound up with petrochemicals processing. Biohydrogen, a high energy clean fuel, is considered as a promising alternative to conventional fossil fuels. Hydrogen gas is a recyclable, efficient (energy density equal to $122 \mathrm{~kJ} / \mathrm{g}$ ) and clean fuel with no $\mathrm{CO}_{2}$ emissions [1-4]. In addition, $\mathrm{H}_{2}$ can be used as a reactant in hydrogenation processes (in order to produce lower molecular weight compounds), as well as an $\mathrm{O}_{2}$ scavenge. Due to increasing need for hydrogen energy, in the recent years much progress has been made to determine effective and efficient methods of biohydrogen production.

Many methods to produce biohydrogen have been studied, but most of them are energy intensive and it makes hydrogen production expensive. Currently, about 96\% of hydrogen comes from processes based on fossil fuels [5]. Alternative methods of hydrogen generation include electrolysis of water, biophotolysis and biological production. Biological hydrogen production offers the benefits of clean gas, simple technology and is a more attractive potential than the current chemical methods. Hence, generate biohydrogen from renewable source is a promising method, which allows to make

* Corresponding author.

E-mail address: audrey.soric@centrale-marseille.fr (A. Soric). 
hydrogen a clean and cheap energy carrier. Among the various pathways able to produce hydrogen from biomass, dark fermentation seems to be one of the most attractive processes [6-9]. During dark fermentation biohydrogen and others products are produced via an heterotrophic mechanism in anaerobic conditions, in which carbohydrates are used as the energy and carbon source [10]. It is recognized as an emerging way ahead, because it does not require external energy to drive the process or large surface area to capture the necessary light, it also can use a wide range of substrates, and different pure and mixed cultures [11]. Production of biohydrogen by mixed cultures is preferred from an engineering point of view, because it can be integrated with wastewater treatment systems. Using organic wastes reduces waste disposal problems [12] and it can minimize hydrogen production cost in scaled-up systems [13]. Furthermore, the acids produced during this process (mainly butyric, acetic and propionic acids) can be used for many industrial purposes. Basis dark fermentation provides an economically feasible and environmental friendly process.

Several studies have investigated various sources of carbon, including: sucrose [7,14-21], glucose [20,22-27], galactose [28] and fructose [16] as well as different feedstock such as: municipal wastewater [17], yeast factory [3], cheese whey $[18,29,30]$ and oat straw hydrolysate [31]. Mix cultures are characterized by better degradation of organic matter and efficiently consume carbon sources compared to pure microbial species [32]. Moreover, hydrogen production using anaerobic organic waste or wastewater can be done without sterilization, which has large economic benefits. Hydrogen yield obtained from mixed culture is generally lower than from pure cultures, due to hydrogen consumption by microorganisms [33]. Thus, inoculum pretreatment is needed and it is one of the most debated issues nowadays. Effective methods of pre-treatment allow to inhibit the methaneproducing bacteria activity, sulfidogenic microorganisms, as well as harvest anaerobic spore-forming bacteria. In general, pretreatment methods include: heat $[34,35]$ and acid shock [35,36], mechanical pretreatment [37], ultrasonic [38] and electric field [39]. However, the most commonly used method for treatment of mixed culture is heat-shock, which obtains the best performance and higher $\mathrm{H}_{2}$-production rates than acid shock $[40,41]$. Furthermore, thermal treatment is simple, inexpensive and effective. It requires temperatures around $100{ }^{\circ} \mathrm{C}$ for durations of $15-120 \mathrm{~min}$ in order to suppress nonspore-forming bacteria [23,42-45]. However, the pretreatment at $90{ }^{\circ} \mathrm{C}$ for $10 \mathrm{~min}$ has also been used [46-48].

In general, hydrogen yield is related to the dominant microorganisms and operating parameters used for fermentation process. It has been demonstrated, that the performance of hydrogen production via dark fermentation is influenced significantly by factors such as $\mathrm{pH}[23,49,50]$, temperature $[50,51]$, HRT $[3,14,17,18,23,24,27]$ and hydrogen partial pressure [52]. Specifically, $\mathrm{pH}$ has the great influence on hydrogen production, because of it affects on the hydrogenase activity, microbial communities, their structure and metabolism. Therefore, in order to keep medium $\mathrm{pH}$ at the optimum value (between 5.5 and 7.8), dark fermentation process has been commonly carried out with $\mathrm{pH}$ control systems and buffers such as sodium hydroxide $(\mathrm{NaOH})$, sodium bicarbonate $\left(\mathrm{NaHCO}_{3}\right)$, hydrochloric acid $(\mathrm{HCl})$ and phosphoric acid $\left(\mathrm{H}_{3} \mathrm{PO}_{4}\right)$ [14-17,19,21-27]. However, from an industrial application point of view, hydrogen production without a $\mathrm{pH}$ buffer addition offers the major economic and environmental advantages.

Although many efforts have been made to produce hydrogen in dark fermentation, obtained values of hydrogen yield are still low (Table 1). Therefore, improving the efficiency of $\mathrm{H}_{2}$ production poses a major challenge, because it determines the economic viability of the process. Moreover, the improvement in yields of hydrogen production from dark fermentation is a key step towards its commercialization.

Among biological reactors employed in biohydrogen production, anaerobic packed bed reactors (APBRs) are one of the most commonly used. Reactors employing immobilization systems generally show large volumes of biomass accumulation on the support medium [53]. Moreover, maintaining a high biomass inventory in biofilm reactors gives robustness against product inhibition [3]. In comparison to conventional anaerobic treatment systems, biofilm reactors could significantly reduce start-up time and increase organic loading rates up to fivefold [49]. In addition, one of the major advantages of immobilized cell technology is that there is no cell washout at high dilution rates, whereas in continuous stirred-tank reactor, since biomass has the same retention time as the liquid phase, washout of microorganisms can occur at short values of HRT [54]. Also, the construction and operation of packed bed reactors are relatively simple. However, a disadvantage of APBRs is that mixing is not completely achieved, leading to higher mass transfer resistance [55]. Therefore, $\mathrm{pH}$ gradient distribution along a reactor column leads to a heterogeneous distribution of microbial activity and thus high hydrogen yield cannot be maintained consistently [56]. To overcome this disadvantage, recirculation flow of a liquid phase can be used. A review of the literature has indicated that studies focused on a long-term hydrogen production via dark fermentation in ABPRs, equipped with the system for back-mixing, are limited to only few papers $[19,22,27]$. Fontes Lima and Zaiat [19] have demonstrated the positive effect of a liquid recirculation on $\mathrm{H}_{2}$ production via dark fermentation in APBRs. The aforementioned authors have found that the optimum value of the recycle ratio is equal to 0.5-0.6. Based on this, in Ref. [22] a packed bed biofilm reactor with a liquid recycle (at $60 \%$ of the feed flow rate) was applied. In turn, dos Reis and Silva [27] have investigated the impact of HRT (in the range from 1 to $8 \mathrm{~h}$ ) on hydrogen and ethanol coproduction in anaerobic packed bed reactors equipped with effluent recycling. However, in mentioned papers $[19,22,27]$, in order to improve biohydrogen production, $\mathrm{pH}$ control systems have been used.

In response to the state of the existing literature, the aim of this study was to evaluate the effect of theoretical hydraulic retention time on hydrogen yield (HY), hydrogen productive rate (HPR) and composition of soluble microbial products in an anaerobic packed bed biofilm reactor equipped with recirculation flow of soluble products, inoculated with a mesophilic sludge, without $\mathrm{pH}$ buffer addition. 
Table 1 - Hydrogen yield and soluble microbial products obtained in APBRs.

\begin{tabular}{|c|c|c|c|c|c|c|c|c|c|c|c|c|}
\hline Carrier material & Inoculum/pretreatment & Substrate & COD $(g / L)$ & HRT (h) & $\mathrm{T}\left({ }^{\circ} \mathrm{C}\right)$ & $\underset{\text { (inlet) }}{\mathrm{pH}}$ & $\begin{array}{c}\mathrm{pH} \\
\text { control } \\
\text { system }\end{array}$ & $\begin{array}{c}\text { HY average } \\
\text { (mol } \mathrm{H}_{2} / \mathrm{mol} \\
\text { substrate) }\end{array}$ & $\begin{array}{l}\text { Recirculation } \\
\text { flow }\end{array}$ & $\begin{array}{c}\text { Homoacetogenic } \\
\text { activity }\end{array}$ & $\begin{array}{l}\text { Soluble } \\
\text { products }\end{array}$ & Reference \\
\hline $\begin{array}{l}\text { Low-density } \\
\text { polyethylene }\end{array}$ & Natural fermentation/NI & Sucrose & NI & 10.2 & 55.0 & 6.5 & - & 1.6 & - & NI & $\begin{array}{l}\mathrm{HAc}, \mathrm{HBu}, \mathrm{HPr} \\
\text { HVa, HCp, EtOH }\end{array}$ & [7] \\
\hline Expanded clay & $\begin{array}{l}\text { Municipal sewage } \\
\text { sludge/Acidic }\end{array}$ & Sucrose & 20.0 & $0.5-5.0$ & 35.0 & 6.7 & + & $0.1-1.1^{\mathrm{a}}$ & - & - & $\begin{array}{l}\mathrm{HAc}, \mathrm{HPr} \\
\mathrm{HBu}, \mathrm{EtOH}\end{array}$ & [14] \\
\hline Activated carbon & $\begin{array}{l}\text { Municipal sewage } \\
\text { sludge/Acidic }\end{array}$ & Sucrose & 20.0 & $0.5-2.0$ & 35.0 & 6.7 & + & NI & - & - & $\begin{array}{l}\mathrm{HAc}, \mathrm{HPr} \\
\mathrm{HBu}, \mathrm{EtOH}\end{array}$ & [14] \\
\hline Activated carbon & $\begin{array}{l}\text { Municipal sewage } \\
\text { sludge/Acidic }\end{array}$ & Sucrose & 20.0 & $1.0-3.0$ & 35.0 & 6.7 & + & NI & - & - & $\begin{array}{l}\mathrm{HAc}, \mathrm{HPr} \\
\mathrm{HBu}, \mathrm{EtOH}\end{array}$ & [14] \\
\hline Plastic rings & Mixed cultures/NI & Sucrose & 10.0 & $2.0-30.0$ & 26.0 & 7.8 & + & $0.8-1.2$ & - & - & NI & [15] \\
\hline $\begin{array}{l}\text { Polyethylene- } \\
\text { octene elastomer }\end{array}$ & $\begin{array}{l}\text { Municipal sewage } \\
\text { sludge/Acidic }\end{array}$ & Sucrose & 20.0 & 4.0 & 35.0 & 6.0 & + & 0.9 & - & - & $\begin{array}{l}\mathrm{HAc}, \mathrm{HBu} \\
\text { HPr, EtOH }\end{array}$ & [16] \\
\hline Activated carbon & $\begin{array}{l}\text { Municipal sewage } \\
\text { sludge/Acidic }\end{array}$ & Sucrose & 20.0 & $0.5-4.0$ & 35.0 & 6.7 & + & $1.2-3.9$ & - & - & $\begin{array}{l}\text { HAc, HBu, } \\
\text { HPr, HVa, EtOH }\end{array}$ & [17] \\
\hline Ceramic & Soft drink wastewater/NI & Sucrose & 10.0 & $1.5-24.0$ & 55.0 & $4.5-5.5$ & - & 3.0 & - & - & $\mathrm{HAc}, \mathrm{HBu}$ & [18] \\
\hline $\begin{array}{l}\text { Low-density } \\
\text { polyethylene }\end{array}$ & Natural fermentation/NI & Sucrose & NI & 2.0 & 25.0 & 6.5 & + & $0.9-1.4$ & + & + & $\begin{array}{l}\mathrm{HAc}, \mathrm{HBu}, \mathrm{HPr} \\
\text { EtOH }\end{array}$ & [19] \\
\hline $\begin{array}{l}\text { Low-density } \\
\text { polyethylene }\end{array}$ & Natural fermentation/NI & Sucrose & 2.0 & 2.0 & 25.0 & NI & NI & 0.6 & - & + & $\begin{array}{l}\mathrm{HAc}, \mathrm{HBu}, \mathrm{HPr} \\
\mathrm{HLc}, \mathrm{EtOH}\end{array}$ & [20] \\
\hline $\begin{array}{l}\text { Low-density } \\
\text { polyethylene }\end{array}$ & Natural fermentation/NI & Glucose & 2.0 & 2.0 & 25.0 & NI & NI & 1.2 & - & - & $\begin{array}{l}\mathrm{HAc}, \mathrm{HBu}, \mathrm{HPr} \\
\mathrm{HLc}, \mathrm{EtOH}\end{array}$ & [20] \\
\hline $\begin{array}{l}\text { Low-density } \\
\text { polyethylene }\end{array}$ & $\begin{array}{l}\text { Anaerobic sludge } \\
\text { from UASB } \\
\text { reactors/Heat, acidic }\end{array}$ & Sucrose & 2.0 & 2.0 & 25.0 & 6.5 & + & $0.7-2.1$ & - & + & $\begin{array}{l}\mathrm{HAc}, \mathrm{HBu}, \mathrm{HPr} \\
\text { EtOH }\end{array}$ & [21] \\
\hline $\begin{array}{l}\text { Low-density } \\
\text { polyethylene }\end{array}$ & $\begin{array}{l}\text { Municipal sewage } \\
\text { sludge/Heat }\end{array}$ & Glucose & $2.0-64.0$ & 8.0 & 37.0 & 6.5 & + & 1.0 & + & - & $\mathrm{HAc}, \mathrm{HBu}, \mathrm{HPr}$ & [22] \\
\hline $\begin{array}{l}\text { Low-density } \\
\text { polyethylene }\end{array}$ & $\begin{array}{l}\text { Municipal sewage } \\
\text { sludge/Heat }\end{array}$ & Glucose & $2.0-64.0$ & 8.0 & 37.0 & 6.5 & + & 2.0 & + & - & $\mathrm{HAc}, \mathrm{HBu}, \mathrm{HPr}$ & [22] \\
\hline Polyethylene & $\begin{array}{l}\text { Municipal sewage } \\
\text { sludge/Heat }\end{array}$ & Glucose & NI & $12.0-24.0$ & 37.0 & $5.0-6.5$ & + & $0.7^{c}$ & - & + & $\begin{array}{l}\text { HLc, HAc, HPr, } \\
\text { HBu, HFr, HS }\end{array}$ & [23] \\
\hline Polyethylene & $\begin{array}{l}\text { Municipal sewage } \\
\text { sludge/Heat }\end{array}$ & Glucose & 8.0 & $2.0-24.0$ & 37.0 & 5.7 & + & NI & - & + & $\begin{array}{l}\text { HLc, HAc, HPr, } \\
\text { HBu, HFr, HS }\end{array}$ & [24] \\
\hline Activated carbon & $\begin{array}{l}\text { Municipal sewage } \\
\text { sludge/Heat }\end{array}$ & Glucose & 20.0 & 4.0 & 40.0 & $6.0-7.0$ & + & 0.9 & - & - & $\begin{array}{l}\mathrm{HAc}, \mathrm{HPr}, \mathrm{HBu} \text {, } \\
\text { EtOH }\end{array}$ & [25] \\
\hline Inert stone chips & $\begin{array}{l}\text { Municipal sewage } \\
\text { sludge/Heat, } \\
\text { acidic }\end{array}$ & Glucose & 5.0 & 24.0 & 28.0 & $6.0-7.0$ & + & $0.014-0.016^{b}$ & - & - & $\mathrm{HAc}, \mathrm{HPr}, \mathrm{HBu}$ & [26] \\
\hline Expanded clay & $\begin{array}{l}\text { Swine slaughterhouse } \\
\text { sludge/Heat }\end{array}$ & Glucose & 3.5 & $1.0-8.0$ & 25.0 & $4.0-5.0$ & + & $1.2-2.4$ & + & - & $\begin{array}{l}\mathrm{HAc}, \mathrm{HBu}, \mathrm{HPr} \\
\text { EtOH, MetOH }\end{array}$ & [27] \\
\hline
\end{tabular}




\section{Materials and methods}

\section{Reactor design and support material}

Anaerobic packed bed reactor (APBR) with a cylindrical jacketed glass was used for the experiments (Fig. 1). The inner diameter was $10 \mathrm{~cm}$, the height $40 \mathrm{~cm}$ and the total working volume $2.1 \mathrm{~L}$. The reactor was filled with Kaldnes ${ }^{\circledR}$ biofilm carrier $(10 \mathrm{~mm})$, made by high density PE. The material had a density of approximately $0.95 \mathrm{~g} / \mathrm{cm}^{3}$ and a porosity of $90 \%$.

\section{Heat-treatment of $\mathrm{H}_{2}$-producing sludge and medium}

The inoculum used in this study was an anaerobic mesophilic sludge obtained from an urban wastewater treatment plant (WWTP) in Aix-en-Provence, France. The bacterial community structures of sludge sampled from this station has already been studied and presented in Ref. [57]. According to this work, we supposed that the sludge used in the present study was the most predominant by phyla Proteobacteria, Bacteroidetes and Actinobacteria. The support of this hypothesis is the fact, that members of these phyla have already been found as dominated in mixed anaerobic consortia producing biohydrogen [58-60].

Before seeded into the reactor, the sludge $(10 \% \mathrm{v} / \mathrm{v})$ was heat-treated in anaerobic conditions at $100^{\circ} \mathrm{C}$ for $1 \mathrm{~h}$ to inhibit the methane-producing bacteria activity and harvest anaerobic spore-forming bacteria [42,43]. It has been demonstrated that Clostridium species in heat-treated sludge are the most commonly identified bacteria responsible for biohydrogen production [61-63]. In order to investigate the influence of substrate type on instability in the biohydrogen production, as a carbon source glucose and sucrose have been used (initial concentration: $5000 \mathrm{mg} / \mathrm{L}$ ) (Table 2). The medium used for biohydrogen production consisted also of 9 following inorganic supplements (mg/L): $\mathrm{NH}_{4} \mathrm{Cl}, 500 ; \mathrm{K}_{2} \mathrm{HPO}_{4}, 250 ; \mathrm{KH}_{2} \mathrm{PO}_{4}$,
250; $\mathrm{MgCl}_{2}, 300 ; \mathrm{CoCl}_{2}, 25 ; \mathrm{CuCl}_{2}, 10 ; \mathrm{MnCl}_{2}, 15 ; \mathrm{CaCl}_{2}, 5 ; \mathrm{FeCl}_{3}$, 25 . The reactor was operated without any additional reagents for $\mathrm{pH}$ adjustment.

\section{Cell immobilization}

Prior to cell immobilization, the reactor was purged with nitrogen gas for $20 \mathrm{~min}$ to ensure anaerobic conditions. $230 \mathrm{~mL}$ of pretreated seed sludge with $2.070 \mathrm{~L}$ of synthetic wastewater were injected at the inlet of the immobilized reactor. In order to promote adhesion and growth of the biofilm on the carrier surface, the reactor was operated in a batch mode by recirculation of the feeding solution by a peristaltic pump at a HRT equal to $2 \mathrm{~h}$ during the first $29.5 \mathrm{~h}$. Circulation used for the purpose of cell attachment was terminated when $70 \%$ of biomass was attached to the biofilm carrier. After the activation period reactor was switched on to a continuous mode with a designated theoretical hydraulic retention times, began with $5 \mathrm{~h}$.

\section{Reactor setup and operating conditions}

The APBR was fed with a synthetic wastewater containing carbon source (glucose/sucrose) and $10 \%$ (v/v) of heat-treated sludge. Production of biohydrogen by the immobilized culture was continuously operated. Fresh inlet was fed to the reactor by a peristaltic pump according to the predetermined HRT values. Liquid effluent was collected from the side of the reactor, while the gaseous effluent was collected from the top. Flow rate of the biogas was measured by a glass soap bubble flow meter. In order to decrease dissolved gas $\left(\mathrm{H}_{2}\right.$ and $\left.\mathrm{CO}_{2}\right)$ concentrations and minimize process inhibition as well as remove dissolved oxygen, the reactor was purged with nitrogen every day (100 mL/min, $20 \mathrm{~min})$. This also allowed to the creation of anaerobic conditions. The temperature of the reactor was set at $37^{\circ} \mathrm{C}$ by recirculation heated water from a thermostatic bath through the column water jackets. The

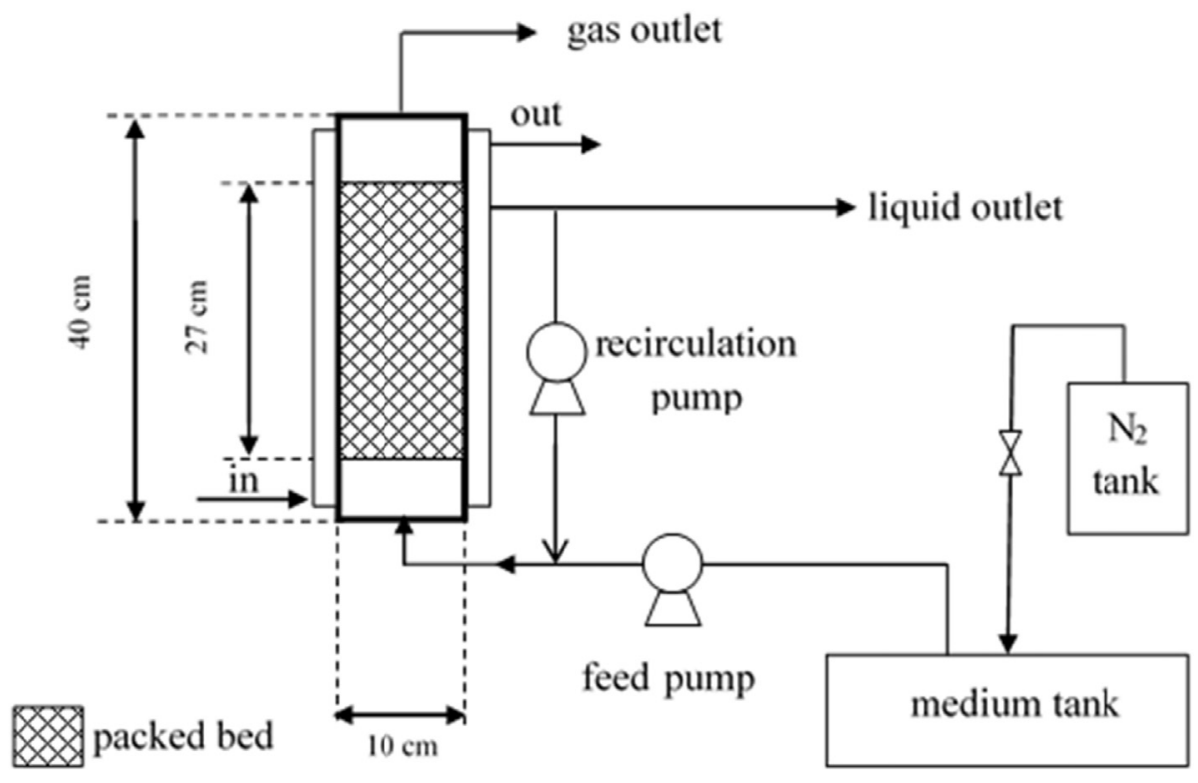

Fig. 1 - Packed bed biofilm reactor for continuous biohydrogen production. 
Table 2 - Operational periods during the fermentation process.

\begin{tabular}{|c|c|c|c|c|}
\hline Operational phase & I & II & III & IV \\
\hline Time (days) & 21 & 21 & 21 & 14 \\
\hline Substrate & Glucose & & Sucrose & \\
\hline HRT (h) & 5 & 3 & 2 & 1 \\
\hline Inlet flow rate $(\mathrm{L} / \mathrm{h})$ & 0.40 & 0.66 & 1.00 & 2.00 \\
\hline Recirculation flow rate $(\mathrm{L} / \mathrm{h})$ & 0.20 & 0.33 & 0.50 & 1.00 \\
\hline Flow rate recirculation/inlet (-) & \multicolumn{4}{|c|}{0.5} \\
\hline
\end{tabular}

study was divided into five experimental phases (Table 2) with 14-21 days long each one, corresponding to the theoretical values of HRT from 5 to $1 \mathrm{~h}$. Flow rates in an inlet were equal to: $0.40 ; 0.66 ; 1.0$ and $2.0 \mathrm{~L} / \mathrm{h}$. In order to increase liquid-gas mass transfer, recycle of a liquid phase was applied. Effluent was recycled through a recycle pump connecting effluent outlet and feed inlet. Based on finding presented in Ref. [19] a ratio between flow in the recirculation line and the inlet equal to 0.5 has been applied. Therefore, the recycle flow rates were equal to $0.20 ; 0.33 ; 0.50$ and $1.0 \mathrm{~L} / \mathrm{h}$, respectively, for each theoretical values of HRT. The reactor was operated during 77 days, without addition of an alkalinity agent. The concentration of gas products and soluble metabolites (volatile fatty acids and ethanol) were evaluated during all operation phases at designated time intervals. $\mathrm{pH}$ and concentrations of carbon source in the influent and effluent of the reactor were also recorded. The results reported in the present paper are the average values for each phases.

\section{Analytical methods}

The carbohydrates concentrations of the reactor's influent and effluent were measured using Standards Methods (via phenol-sulfuric acid method). Concentrations of volatile fatty acids (VFA) and alcohols were also measured by gas chromatography (Agilent Technologies) 7890B GC system equipped with DB-WAX column $(30 \mathrm{~m} \times 0.25 \mathrm{~mm} \times 0.25 \mu \mathrm{m})$. Before analysis, effluent samples were filtered through a $0.2 \mu \mathrm{m}$ membrane. The temperatures of the injector and detector were $250{ }^{\circ} \mathrm{C}$ and $300{ }^{\circ} \mathrm{C}$, respectively. The oven temperature increased from $100{ }^{\circ} \mathrm{C}$ by a ramp-up of $10^{\circ} \mathrm{C} / \mathrm{min}$ for $5 \mathrm{~min}$, and was held at a final temperature of $250{ }^{\circ} \mathrm{C}$ for $12 \mathrm{~min}$. Helium was used as the carrier gas with a flow rate of $3 \mathrm{~mL} / \mathrm{min}$. The composition of the gas in the headspace of the reactor was determined by a Varian 3800 Gas Chromatograph. The analyses of solids (total suspended solids - TSS and total volatile solids - TVS) and $\mathrm{pH}$ were performed according to Standard Methods (APHA, 1998). A total organic carbon (TOC) analyzer (TOC-V Shimadzu) was used to measure the organic content in the feed solution and the effluent of the reactor. The procedure followed for biofilm quantification was adapted from Standard Methods [64].

\section{Temperature control}

Since temperature is one of the most important factors which has the significant influence on the activities of hydrogenproducing bacteria and the fermentative hydrogen production, the temperature profile inside the reactor was carefully investigated. Nine T-type thermocouples were used, which were arranged along the vertical axis $(\mathrm{H})$ at $135 \mathrm{~mm}$ from each other and along a horizontal axis ( $\mathrm{r}$ ) at $25 \mathrm{~mm}$ from each other. Installed positions of thermocouples are shown in Fig. 2. In addition, two thermocouples have been used to measure temperature in the inlet and outlet of the jacket and one in the inlet of the reactor. Temperature was measured with 5-s intervals during 77 days with the accuracy equal to $0.01{ }^{\circ} \mathrm{C}$.

\section{Results and discussion}

\section{pH and temperature profile}

$\mathrm{pH}$ in the influent and effluent of the reactor was stable (Fig. 3) and equal to $4.49 \pm 0.46$ and $3.63 \pm 0.51$, respectively.

The values of average temperature inside the reactor at different axial and horizontal positions are presented in Fig. 4. In general, during 77 days of the fermentation process, the average temperature inside the APBR was equal to $36.60^{\circ} \mathrm{C}$. However, it should be noted, that the specific average value depends on the place inside the reactor and it increases along a height and decreases along a radius of the packed bed. The highest average temperature $\left(37.46 \pm 0.86^{\circ} \mathrm{C}\right)$ was noted at the position $\mathrm{r}=0$ and $\mathrm{H}=0.135 \mathrm{~m}$. In turn, the lowest average temperature $\left(35.14 \pm 1.28^{\circ} \mathrm{C}\right)$ was observed near to the inlet of reactor $(r=0.025 \mathrm{~m}$ and $\mathrm{H}=0)$. The highest difference of average temperature along the horizontal and the vertical axis was equal to $1.74{ }^{\circ} \mathrm{C}$ and $2.03{ }^{\circ} \mathrm{C}$ respectively. The average values of temperature in the inlet and outlet of the reactor

thermocouple

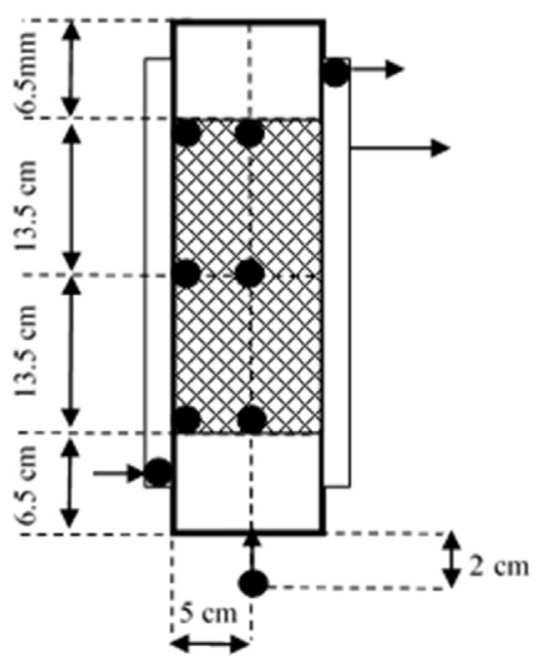

Fig. 2 - Installed positions of thermocouples for measuring temperature in a packed bed. 


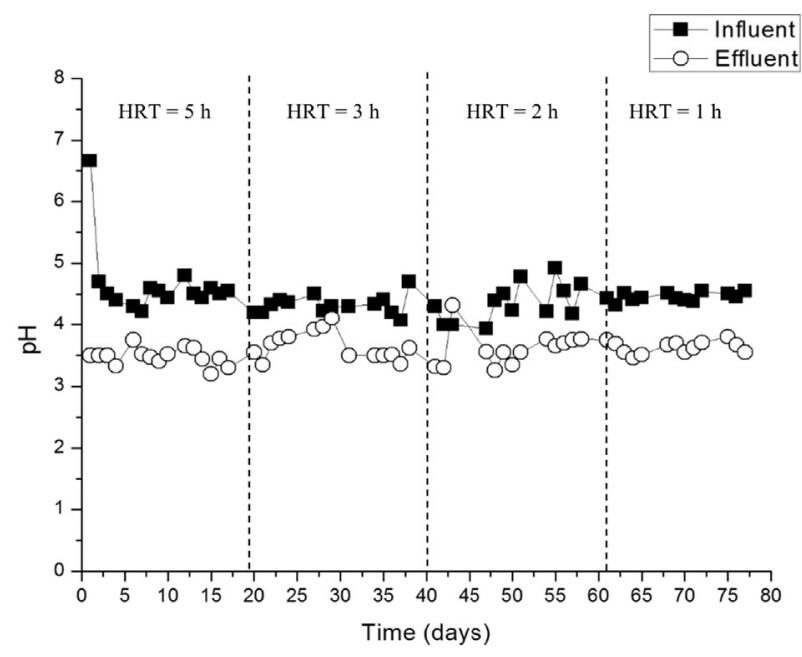

Fig. 3 - Performance of influent and effluent $\mathrm{pH}$ during the operation.

were constant and equal to $37.57^{\circ} \mathrm{C}$ and $37.55^{\circ} \mathrm{C}$, respectively. The average temperature of the feeding solution after mixing was equal to $25.50^{\circ} \mathrm{C}$.

\section{Biohydrogen production}

Instability in the hydrogen production

The produced biogas was composed of $\mathrm{H}_{2}$ and $\mathrm{CO}_{2}$. No methane was detected throughout all the periods of the APBR operation, indicating that the method used for pretreatment of the inoculum leads to effective removing methanogen bacteria. However, hydrogen production fluctuated strongly for both carbon sources (glucose and sucrose) over the range of experimental conditions. Fig. 5 shows obtained values of $\mathrm{H}_{2}$ content in the biogas, $\mathrm{HY}\left(\mathrm{mol} \mathrm{H}_{2}\right.$ produced/mol substrate consumed) and HPR (volume $\mathrm{H}_{2}$ produced/ $\mathrm{H}_{2}$ evolution time/ reactor volume) during all reactor operation.

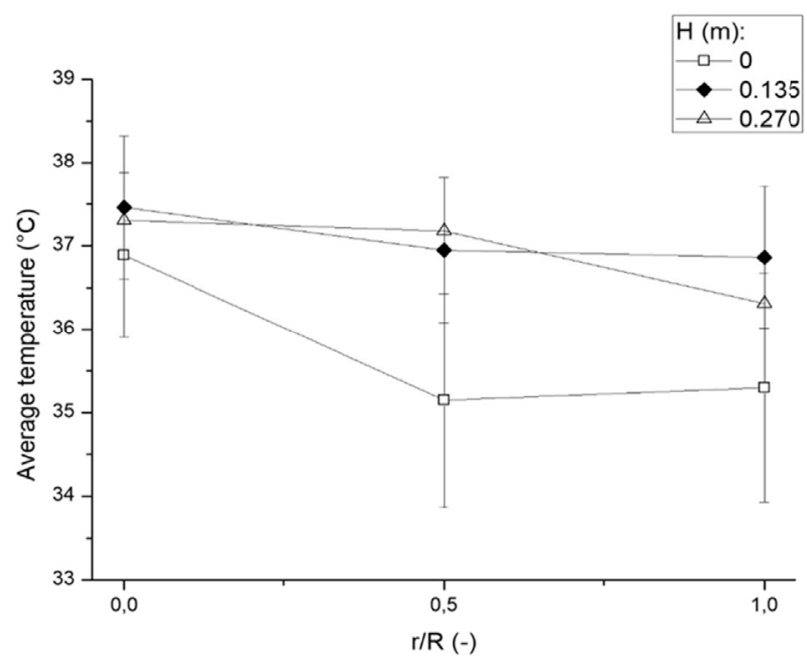

Fig. 4 - Average values of temperature inside the reactor during 77 days of the operation. $\mathbf{r}$ - distance from the wall, $\mathrm{R}$ - reactor radius, $\mathrm{H}$ - distance from the bottom.

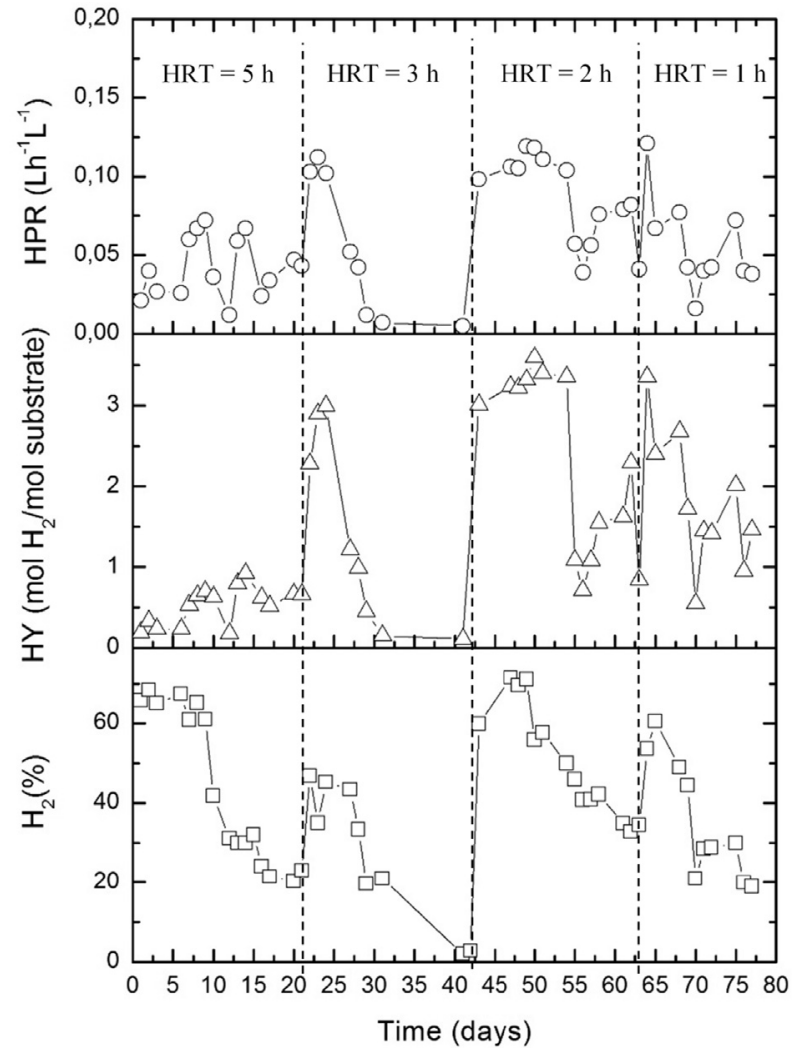

Fig. 5 - Content of $\mathrm{H}_{2}$ in a biogas, $\mathrm{HY}$ and HPR during the fermentation process.

The content of $\mathrm{H}_{2}$ in the biogas was constant $(64.78 \pm 2.98 \%)$ during the first 9 days of operation and then it drastically decreased to the value $22.94 \%$ (21th day of process). Further decreasing values of HRT to 3; 2 and $1 \mathrm{~h}$ led to increasing $\mathrm{H}_{2}$ content to values equal to about $45.28 \%, 71.49 \%$ and $60.60 \%$, respectively, but just for short periods of time (3-4 days). In general, systematic decreasing of $\mathrm{H}_{2}$ concentration has been observed throughout the process.

Instability of hydrogen production in APBRs operation has been widely reported in the literature $[7,19-21,23,24]$ and it is a typical issue, which occurs during long-term operations of systems inoculated by mixed bacteria cultures. Penteado et al. [21] have credited the instability to the consumption of $\mathrm{H}_{2}$ and $\mathrm{CO}_{2}$ by methanogenic or sulfidogenic organisms. Because in this study methane and hydrogen sulfide were not detected in the gas phase, the consumption of hydrogen by these organisms should be excluded. The most coherent hypothesis is that this instabilities are related to homoacetogenic microorganisms, which use the Wood-Ljungdahl (or acetyl-CoA) pathway, where $\mathrm{CO}_{2}$ and $\mathrm{H}_{2}$ are converting into acetic acid and water through the following reaction [65].

$4 \mathrm{H}_{2}+2 \mathrm{CO}_{2} \rightarrow \mathrm{CH}_{3} \mathrm{COOH}+2 \mathrm{H}_{2} \mathrm{O}$

This pathway was the main responsible for the hydrogen production instabilities in long term operation of APBRs in studies [19-21,23,24].

Homoacetogenic bacteria are strictly anaerobic and belong to: Acetobacterium, Butyribacterium, Clostridium, Eubacterium, Peptostreptococcus and Sporomusa, whereas Clostridium and 
Acetobacterium sp. are the most common [66]. Although their role in dark fermentation is important, it is still not clear [66]. Moreover, the threshold concentrations of $\mathrm{H}_{2}$ and $\mathrm{CO}_{2}$ required are not well characterized. Oh et al. [67] demonstrated, that heat-shock is able to remove methanogenic strain, but may not remove some strains of homoacetogenic bacteria such as same genus Clostridium, which can survive heat shock due to the ability to form high-temperature resistant endospores. According to [66], no effective method is known, which leads to eliminate hydrogen losses via acetogenesis. It is due to the fact, that homoacetogenic bacteria activity does not depend on their source, pretreatment conditions, substrate, type of reactor as well as process parameters. However, Duangmanee et al. [68] demonstrated, that to maintain stability in continuously hydrogen production repeat pre-treatment of inoculum every day is needed. In turn, Luo et al. [33] reported, that pretreatment of the inoculum does not have the influence on the homoacetogenesis inhibition and during fermentative $\mathrm{H}_{2}$ production homoacetogenic activity can be inhibited under thermophilic condition at initial pH equal to 5.5. Moreover, Fontes Lima et al. [20] showed, that substrate may have the influence of $\mathrm{H}_{2}$ production stability. In Ref. [20] the $\mathrm{H}_{2}$ production in two APBRs: fed with glucose and sucrose has been compared. Authors reported that the ABPR fed with sucrose was characterized by instability of $\mathrm{H}_{2}$ production due to homoacetogenic bacteria activity, whereas in the APBR fed with glucose stabilization has been obtained. This result shows differential growth of microorganisms capable of using the Wood-Ljungdahl metabolic pathway on the sucrose and monosaccharide. However, in this study the phenomenon of instability during hydrogen production was supposed to be independent of the carbon source (glucose: phase I and sucrose: phases II-IV).

Effect of HRT on hydrogen yield and hydrogen production rate The maximum theoretical hydrogen yield is equal to $8 \mathrm{~mol} \mathrm{H}_{2} /$ mol sucrose when acetic acid is the main by-product of a fermentation process and it decreases to $4 \mathrm{~mol} \mathrm{H}_{2} / \mathrm{mol} \mathrm{su}$ crose, when butyric acid is dominant in the liquid phase. In order to find out the optimum operating conditions the performances of the reactor were assessed by applying different values of HRT. The average and maximum values of $\mathrm{H}_{2}$ percentage in a biogas, HY and HPR obtained under different HRT are presented in Table 3.

Average values of $\mathrm{H}_{2}$ percentage in the biogas have been noted in the range between $27.68 \% \pm 17.31$ (HRT $=3 \mathrm{~h}$ ) and $50.53 \% \pm 13.82(\mathrm{HRT}=2 \mathrm{~h}$ ). The maximum values of $\mathrm{HY}$ and HPR were equal to $3.60 \mathrm{~mol} \mathrm{H}_{2} / \mathrm{mol}$ sucrose and $0.118 \mathrm{~L} \mathrm{~h}^{-1} \mathrm{~L}^{-1}\left(\mathrm{HRT}=2 \mathrm{~h}, 50^{\text {th }}\right.$ day of fermentation). Average values increased significantly, from $0.52 \pm 0.23$ to $2.35 \pm 1.37 \mathrm{~mol} \mathrm{H}_{2} / \mathrm{mol}$ substrate and from $0.042 \pm 0.018$ to $0.085 \pm 0.270 \mathrm{~L} \mathrm{~h}^{-1} \mathrm{~L}^{-1}$, respectively, when the HRT was decreased from 5 to $2 \mathrm{~h}$. Further decreasing HRT (to $1 \mathrm{~h}$ ) led to decreasing values to $1.80 \pm 0.83 \mathrm{~mol} \mathrm{H}_{2} / \mathrm{mol}$ substrate and $0.056 \pm 0.020 \mathrm{~L} \mathrm{~h}^{-1} \mathrm{~L}^{-1}$. It could be due to the fact, that excessively short HRT led to high flow velocities, which had the influence on flushing out part of the biofilm [6]. This indicates that among applied values of HRT (from 1 to $5 \mathrm{~h}$ ) the best value is equal to $2 \mathrm{~h}$. In general, using a short hydraulic retention time is favorable from an industrial point of view, due to increasing a wastewater flow and upgrading the treatment capacity of the reactor [6].

The impact of HRT on hydrogen production in APBRs has been extensively investigated and presented in the literature $[3,14,17,18,23,24,27]$. For example Chang et al. [14] have demonstrated, that HRT strongly affects hydrogen production in two fixed-bed reactors packed with expanded clay or activated carbon. The optimum values of HRT for these reactors have been reported as 2 and $1 \mathrm{~h}$, respectively. In turn, in studies $[15,18]$ it has been demonstrated, that during $\mathrm{H}_{2}$ production in APBRs, decreasing values of HRT (increasing of the substrate loading rate) leads to increasing $\mathrm{H}_{2}$ content in a biogas, $\mathrm{HY}$ and HPR. According to $[15,18]$ the lower $\mathrm{H}_{2}$ content in the biogas at higher values of HRT $(3-5 \mathrm{~h}$ ) was caused by excessive production of $\mathrm{CO}_{2}$ by bacteria species, which do not produce biohydrogen. Moreover, short HRT led to higher substrate flow and thus to increasing the rate of substrate conversion.

Review of the literature has indicated that maximum average value of hydrogen yield obtained in this study (2.35 $\mathrm{mol} \mathrm{H}_{2} / \mathrm{mol}$ sucrose) was much higher than average values achieved in APBRs for the same carbon source (sucrose) and reported in several previous papers [7,14-16,19-21]. Moreover, in all of the mentioned studies values of medium $\mathrm{pH}$ were kept in the range between 6.0 and 7.8, which is known as favorable for $\mathrm{H}_{2}$ production. For example, Chang et al. [14] for an APBR filled with expanded clay as a support material, operated under HRT between 0.5 and $5 \mathrm{~h}$ and $\mathrm{pH}$ equal to 6.7, have achieved the maximum average value of hydrogen yield equal to $1.1 \mathrm{~mol} \mathrm{H}_{2} / \mathrm{mol}$ sucrose. Li et al. [15], by applying the wide range of HRT values (from 2 to $30 \mathrm{~h}$ ) and $\mathrm{pH}$ medium 7.8, have obtained the maximum average value of $\mathrm{HY}$ $1.22 \pm 0.13 \mathrm{~mol} \mathrm{H}_{2} / \mathrm{mol}$ sucrose. In another study, $\mathrm{HY}$ of $0.9 \mathrm{~mol}$ $\mathrm{H}_{2} /$ mol was achieved in a packed bed biofilm reactor operated under HRT $4 \mathrm{~h}$ and pH 6.0 [16]. In turn, Penteado et al. [21] for an APBR operated under HRT $2 \mathrm{~h}$ and medium $\mathrm{pH} 6.5$, have noted the maximum value of hydrogen yield equal to $2.1 \mathrm{~mol}$ $\mathrm{H}_{2} /$ mol sucrose. It has to be pointed out that in the current

Table 3 - Influence of HRT on $\mathrm{H}_{2}$ content in a biogas, HY and HPR during the fermentation process. Mean values \pm standard deviation.

\begin{tabular}{|c|c|c|c|c|c|c|c|}
\hline \multirow[t]{2}{*}{ Substrate } & \multirow[t]{2}{*}{ HRT (h) } & \multicolumn{2}{|c|}{$\mathrm{H}_{2}$ in a biogas (\%) } & \multicolumn{2}{|c|}{$\mathrm{HY}$ (mol H $\mathrm{H}_{2} / \mathrm{mol}$ substrate) } & \multicolumn{2}{|c|}{$\operatorname{HPR}\left(\mathrm{L} \mathrm{h}^{-1} \mathrm{~L}^{-1}\right)$} \\
\hline & & Average & Maximum & Average & Maximum & Average & Maximum \\
\hline Glucose & 5 & $44.20 \pm 19.47$ & 68.33 & $0.52 \pm 0.23$ & 0.92 & $0.042 \pm 0.018$ & 0.067 \\
\hline \multirow[t]{3}{*}{ Sucrose } & 3 & $27.68 \pm 17.31$ & 46.82 & $1.65 \pm 0.59$ & 3.00 & $0.055 \pm 0.047$ & 0.103 \\
\hline & 2 & $50.53 \pm 13.82$ & 71.49 & $2.35 \pm 1.37$ & 3.60 & $0.085 \pm 0.270$ & 0.119 \\
\hline & 1 & $45.64 \pm 15.15$ & 60.60 & $1.80 \pm 0.83$ & 3.36 & $0.056 \pm 0.020$ & 0.121 \\
\hline
\end{tabular}


study average value of HY was also higher than that obtained in a thermophilic hydrogen-producing system demonstrated in Ref. [7]. Higher value of HY achieved in our work probably results from the use of recirculation line of liquid products. According to Ref. [19] it led to obtain higher mass-transfer fluxes and thus improvement hydrogen production. Therefore, the findings obtained in this study clearly indicate the possibility of biohydrogen production without using $\mathrm{pH}$ buffers in APBRs equipped with a liquid recirculation. Since this solution allows to avoid the use of chemical reagents, it can have the positive impact on environmental and economic aspects of biohydrogen production.

\section{Composition of soluble products}

The concentrations of soluble metabolites were measured every day during the course of hydrogen production. A predominance of acetic acid (HAc), butyric acid ( $\mathrm{HBu})$, propionic acid (HPr) and ethanol (EtOH) have been obtained in all experimental phases (Fig. 6). The same composition of a liquid phase during dark fermentation in APBRs has been observed in several studies [14-16,19,21,25].

During operation, the production of soluble products in the reactor changed. Table 4 shows the average values of the main intermediate products concentration and substrate conversion under different applied values of HRT. It has been observed, that HRT has the significant influence on the average concentration values of acetic and butyric acids, and ethanol. When HRT decreased from 5 to $1 \mathrm{~h}$, production of ethanol and acids: butyric and acetic decreased drastically: from $930 \pm 200$ to $80 \pm 20 \mathrm{mg} / \mathrm{L}, 720 \pm 500$ to $80 \pm 10 \mathrm{mg} / \mathrm{L}$, $690 \pm 110$ to $110 \pm 10 \mathrm{~g} / \mathrm{L}$, respectively. In turn, decreasing of
HRT from 5 to $3 \mathrm{~h}$ did not affect significantly on the propionic acid concentration (decreasing of the average concentration from $340 \pm 30$ to $310 \pm 10 \mathrm{mg} / \mathrm{L}$ ). However, further decreasing from 3 to $1 \mathrm{~h}$ led to decreasing of propionic acid concentration to $70 \pm 10 \mathrm{mg} / \mathrm{L}$. It has been demonstrated, that HRT has also the significant impact on substrate conversion. Decreasing HRT from 5 to $1 \mathrm{~h}$ led to decreasing substrate conversion from $70.69 \% \pm 10.27$ to $9.59 \% \pm 0.82$. This indicates, that low values of HRT reduce the substrate used efficiency. It is due to the fact, that at low values of HRT the substrate residence time in APBR was too short for organic matter degradation. Therefore, for complete substrate fermentation its smaller concentration or higher HRT are required.

There are several pathways for the production of hydrogen, organic acids and EtOH. In general, the determination of the composition of soluble microbial products (SMP) implied the fermentation pathway [47].

In order to evaluate the effect of HRT on the soluble products production, the ratio of each metabolite over the SMP formed was calculated (Table 5). Ethanol was the most common metabolite for HRT between 5 and $2 \mathrm{~h}$ (from $34.47 \%$ to $45.46 \%$ of the SMP), with its concentration ranging between $180 \pm 20$ and $930 \pm 200 \mathrm{mg} / \mathrm{L}$. In general, ethanol is considered as an unfavorable metabolite for biohydrogen production. However, Zhu et al. [69] justified the study with high $\mathrm{H}_{2}$ production with ethanol as a by-product, by suggesting the following pathway

$$
\mathrm{C}_{6} \mathrm{H}_{12} \mathrm{O}_{6}+\mathrm{H}_{2} \mathrm{O} \rightarrow \mathrm{C}_{2} \mathrm{H}_{5} \mathrm{OH}+\mathrm{CH}_{3} \mathrm{COOH}+2 \mathrm{H}_{2}+2 \mathrm{CO}_{2}
$$

For HRT equal to $1 \mathrm{~h}$ dominant was acetic acid $(33.77 \%$ of the SMP) (Table 5). It is understandable that the productivity of all metabolites tends to decrease with decreasing HRT due to

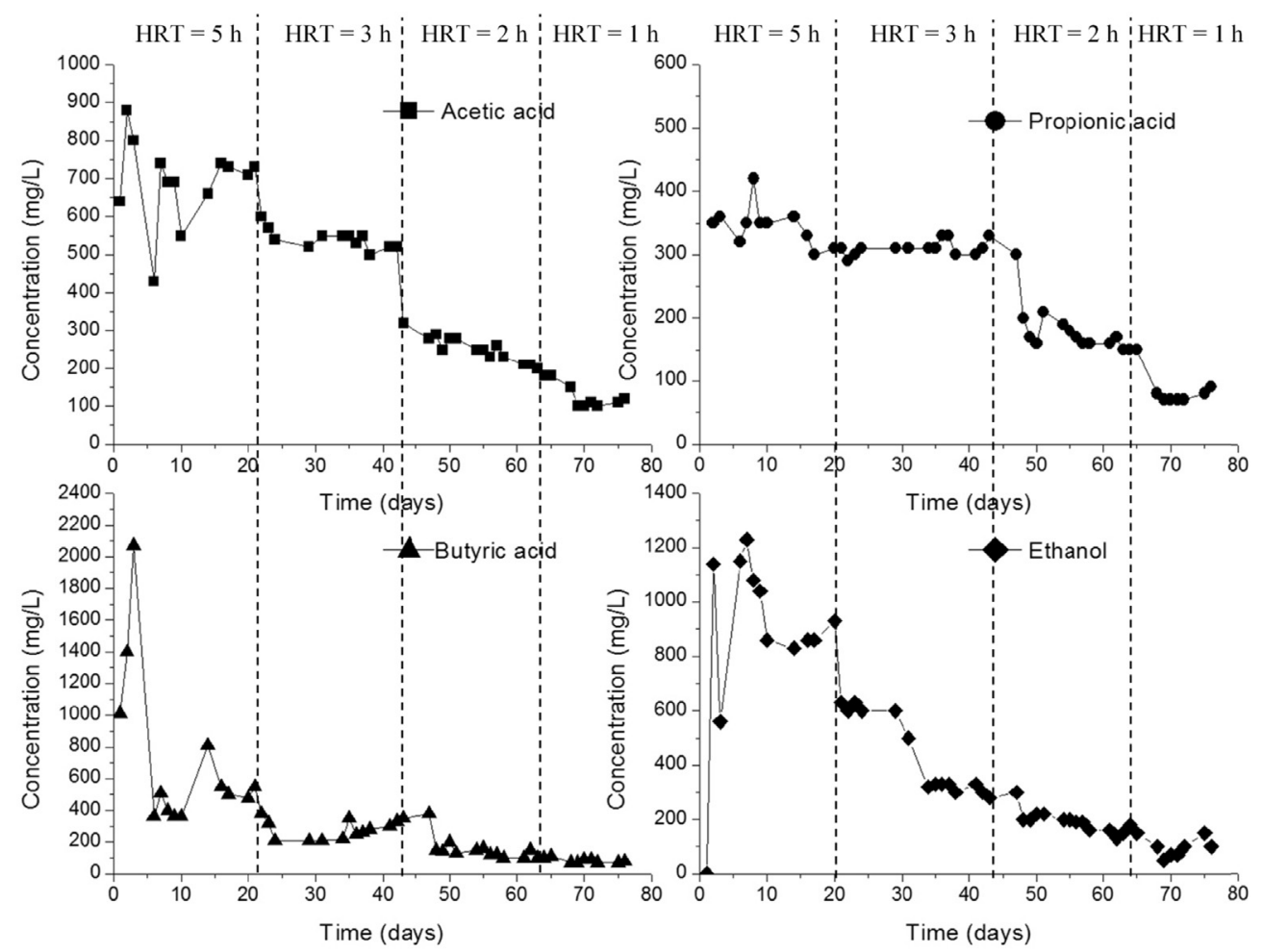

Fig. 6 - Concentration of main by-products during the fermentation process in the APBR. 
Table 4 - Effect of HRT on the average values of by-products concentration and substrate conversion. Mean values \pm standard deviation.

\begin{tabular}{lllll} 
HRT $(\mathrm{h})$ & \multicolumn{4}{c}{ Concentration $(\mathrm{mg} / \mathrm{L})$} \\
\cline { 3 - 5 } Product & \multicolumn{1}{c}{5} & 3 & 2 & 1 \\
\hline Acetic acid & $690 \pm 110$ & $440 \pm 100$ & $220 \pm 40$ & $110 \pm 10$ \\
Propionic acid & $340 \pm 30$ & $310 \pm 10$ & $170 \pm 10$ & $70 \pm 10$ \\
Butyric acid & $720 \pm 500$ & $300 \pm 60$ & $130 \pm 30$ & $80 \pm 10$ \\
Ethanol & $930 \pm 200$ & $370 \pm 120$ & $180 \pm 20$ & $80 \pm 20$ \\
Substrate conversion (\%) & $70.69 \pm 10.27$ & $33.37 \pm 3.36$ & $26.70 \pm 3.07$ & $9.59 \pm 0.82$ \\
\hline
\end{tabular}

Table 5 - Production of soluble metabolites under different operating conditions during dark fermentation process in the APBR.

\begin{tabular}{lcccccccc} 
HRT $(\mathrm{h})$ & HAc/SMP $(\%)$ & HBu/SMP $(\%)$ & HPr/SMP $(\%)$ & EtOH/SMP $(\%)$ & HAc/HBu & TVFA (mM) & SMP (mM) & TVFA/SMP (\%) \\
\hline 5 & 25.84 & 18.38 & 10.32 & 45.46 & $1.42 \pm 0.42$ & 24.27 & 44.49 & 54.55 \\
3 & 31.91 & 14.83 & 18.23 & 35.03 & $2.15 \pm 0.40$ & 14.93 & 22.97 & 64.99 \\
2 & 32.29 & 13.01 & 20.23 & 34.47 & $2.50 \pm 0.30$ & 7.44 & 11.35 & 65.55 \\
1 & 33.77 & 16.74 & 17.42 & 32.07 & $2.02 \pm 0.33$ & 3.68 & 5.42 & 67.96 \\
\hline
\end{tabular}

$\mathrm{HAc}$ - acetic acid, $\mathrm{HBu}$ - butyric acid, $\mathrm{HPr}$ - propionic acid, EtOH - ethanol, HAc/HBu molar acetic-to-butyric acids ratio, TVFA = total volatile fatty acids, TVFA $=\mathrm{HAc}+\mathrm{HBu}+\mathrm{HPr}, \mathrm{SMP}=$ TVFA + EtOH

decreasing substrate conversion (from $70.69 \% \pm 10.27$ to $9.59 \% \pm 0.82)$.

According to $[1,2]$ the $\mathrm{HAc} / \mathrm{HBu}$ ratio has been used as an indicator of hydrogen production. The acetic pathway is considered as the most effective pathway in dark fermentation process. In general, a higher $\mathrm{HAc} / \mathrm{HBu}$ ratio gives a higher theoretical $\mathrm{H}_{2}$ yield, according to the following stoichiometric equations

$\mathrm{C}_{6} \mathrm{H}_{12} \mathrm{O}_{6}+2 \mathrm{H}_{2} \rightarrow 2 \mathrm{CH}_{3}+4 \mathrm{H}_{2}+2 \mathrm{CO}_{2}$

$\mathrm{C}_{6} \mathrm{H}_{12} \mathrm{O}_{6} \rightarrow \mathrm{CH}_{3}\left(\mathrm{CH}_{2}\right) \mathrm{COOH}+2 \mathrm{H}_{2}+2 \mathrm{CO}_{2}$

In this study dark fermentation was predominated by the acetic acid pathway. The HAc/HBu ratio increased from 1.42 to 2.50 when the HRT was reduced from 5 to $2 \mathrm{~h}$ (Table 4). The results obtained in the present work confirm that the highest $\mathrm{HAc} / \mathrm{HBu}$ ratio corresponds to the highest biohydrogen yield (Fig. 7). The highest values have been obtained at HRT equal to $2 \mathrm{~h}$ (Fig. 7).

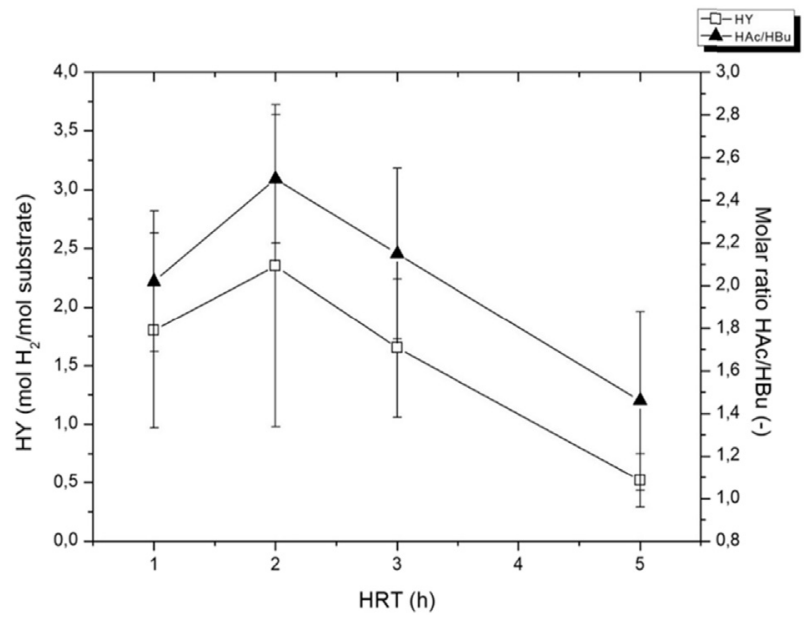

Fig. 7 - Influence of HRT on HY and HAc/HBu.

\section{Cell washout and biofilm analyses}

In order to investigate a successful immobilization, total suspended solids (TSS) in the effluent of the APBR were periodically measured. During all analyzed operational conditions small biomass amount in the effluent of the reactor has been found. It indicates the robustness of the APBR against cell washout in the continuous biohydrogen production. Moreover, it has been demonstrated, that HRT has the impact on TSS amount in the reactor effluent. In general, decreasing value of HRT led to increasing the amount of biomass leaving the reactor (Fig. 8). This phenomenon is due to the fact, that decreasing HRT from $5 \mathrm{~h}$ to $1 \mathrm{~h}$ (HRT $=4 \mathrm{~h}$ was not applied in the present study) was related to increasing the flow velocity in the reactor inlet from $0.40 \mathrm{~L} / \mathrm{h}$ to $5 \mathrm{~L} / \mathrm{h}$. Thus, much more intensive washing out of bacterial cells has been observed.

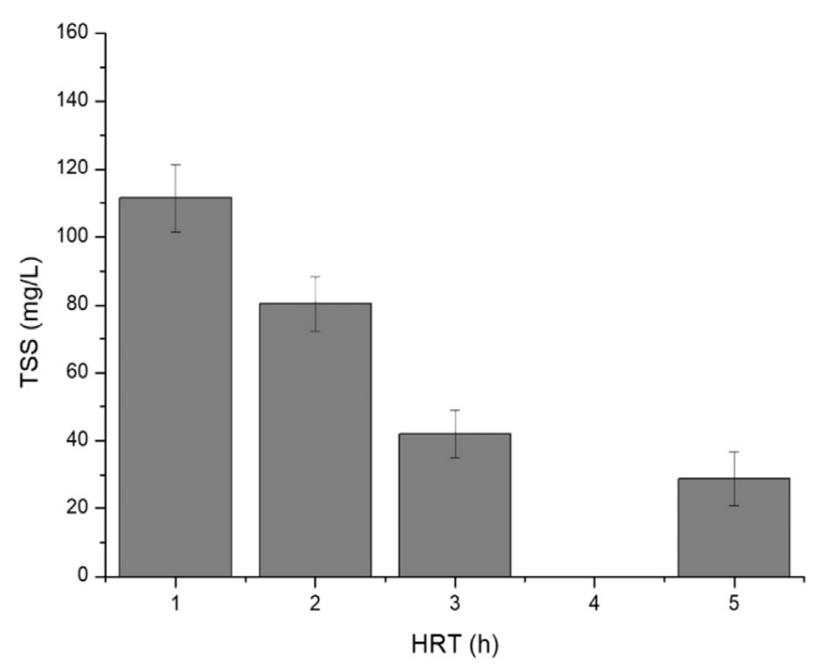

Fig. 8 - Total suspended solids in the outlet of APBR for different HRT. HRT $=4 \mathrm{~h}$ was not applied in the present study. 
Table 6 - TSS and TVS in different parts of the reactor.

\begin{tabular}{lcc} 
Part of the reactor & TSS [mg/g bead] & TVS [mg/g bead] \\
\hline Bottom & $2.6 \pm 0.3$ & $2.2 \pm 0.3$ \\
Half-height & $2.1 \pm 0.3$ & $1.5 \pm 0.2$ \\
Top & $1.5 \pm 0.2$ & $1.1 \pm 0.2$ \\
\hline
\end{tabular}

In order to analyze biofilm quantification, after the experiments, the followings steps were performed:

- Sampling: a known mass of plastic beads samples with attached biofilm was taken respectively from the bottom, half-height and the top of the reactor.

- Separation of the biofilm from plastic beads: the plastic beads were introduced in a vial with distilled water and sonication was performed to separate the biofilm from plastic beads.

- Calculation of TSS and TVS: the extracted biofilm sample was dried at temperature equal to $105^{\circ} \mathrm{C}$ for $24 \mathrm{~h}$ (TSS) and then at $550^{\circ} \mathrm{C}$ for $2 \mathrm{~h}$. The amount of biofilm attached to carrier material was calculated as a difference of weight between samples dried at those two temperatures and expressed as TVS (mg) to mass of plastic beads samples (g).

It has been demonstrated, that concentration of biofilm strongly depends on the reactor height. At the bottom TVS was equal to $2.2 \pm 0.3 \mathrm{mg} / \mathrm{g}$, in the half-height $1.5 \pm 0.2 \mathrm{mg} / \mathrm{g}$ and at the top $1.1 \pm 0.2 \mathrm{mg} / \mathrm{g}$ (average values \pm standard deviation of five replicates) (Table 6). These values are in the conformity with results presented in the previous studies $[2,70]$, where amount of attached biofilm was in the range between 0.20 and $2.10 \mathrm{mg} / \mathrm{g}$. According to [70], the limited biomass growth at the reactor top could be due to a lower value of $\mathrm{pH}$ and accumulation of fermentation products in this part of the reactor. After 77 days of continuous operation about $3.043 \mathrm{~g}$ of TVS were totally present in the reactor.

\section{Conclusions}

The results obtained in the present study show that using anaerobic mesophilic sludge for a long term biohydrogen production in a biofilm reactor performs satisfactorily. It has been shown, that pre-treatment of the sludge at $100{ }^{\circ} \mathrm{C}$ for $1 \mathrm{~h}$ is an effective method to inhibit the methane-producing bacteria activity and harvest anaerobic spore-forming bacteria. In the present study biohydrogen production has been carried out in a low medium pH (inlet: $4.49 \pm 0.46$, outlet: $3.63 \pm 0.51)$. This $\mathrm{pH}$ is the consequence of the mixing of influent and liquid recycle. Thus, the results clearly indicate the opportunity to $\mathrm{H}_{2}$ production without $\mathrm{pH}$ buffer addition, which is environmentally friendly and leads to significant reduce of production costs. Moreover, the present paper demonstrates the possibility to enhance $\mathrm{HY}$ in a dark fermentation process by using recirculation flow in APBRs. Among investigated values of HRT (from 5 to $1 \mathrm{~h}$ ) the highest average values of $\mathrm{HY}\left(2.35 \mathrm{~mol} \mathrm{H}_{2} / \mathrm{mol}\right.$ substrate) and HPR $\left(0.085 \mathrm{~L} \mathrm{~h}^{-1} \mathrm{~L}^{-1}\right)$ have been obtained at HRT equal to $2 \mathrm{~h}$. It has been shown, that instability of $\mathrm{H}_{2}$ production, which occurred throughout all operational periods, is supposed to be independent of the carbon source. Difficulty in obtaining stable $\mathrm{H}_{2}$ productivity could be caused by anaerobic homoacetogenic microorganisms, which are involved in the uptake of $\mathrm{H}_{2}$ and $\mathrm{CO}_{2}$ through Wood-Ljungdahl pathway.

\section{Acknowledgment}

This research was supported by the French National Research Agency (ANR, France) in the frame of $A^{*}$ MIDEX project $\left(n^{\circ}\right.$ ANR-11-IDEX-0001-02)

\section{REFERENCES}

[1] de Amorim ELC, Sader LT, Silva EL. Effect of substrate concentration on dark fermentation hydrogen production using an anaerobic fluidized bed reactor. Appl Biochem Biotechnol 2012;166:1248-63. https://doi.org/10.1007/s12010011-9511-9.

[2] Barros AR, Adorno MAT, Sakamoto IK, Maintinguer SI, Varesche MBA, Silva EL. Performance evaluation and phylogenetic characterization of anaerobic fluidized bed reactors using ground tire and pet as support materials for biohydrogen production. Bioresour Technol 2011;102:3840-7. https://doi.org/10.1016/j.biortech.2010.12.014.

[3] Keskin T, Aksöyek E, Azbar N. Comparative analysis of thermophilic immobilized biohydrogen production using packed materials of ceramic ring and pumice stone. Int J Hydrogen Energy 2011;36:15160-7. https://doi.org/10.1016/ j.ijhydene.2011.08.078.

[4] Show KY, Lee DJ, Tay JH, Lin CY, Chang JS. Biohydrogen production: current perspectives and the way forward. Int J Hydrogen Energy 2012;37:15616-31. https://doi.org/10.1016/ j.jjhydene.2012.04.109.

[5] Koumi Ngoh S, Njomo D. An overview of hydrogen gas production from solar energy. Renew Sustain Energy Rev 2012;16:6782-92. https://doi.org/10.1016/j.rser.2012.07.027.

[6] Barca C, Soric A, Ranava D, Giudici-Orticoni M-T, Ferrasse J$\mathrm{H}$. Anaerobic biofilm reactors for dark fermentative hydrogen production from wastewater: a review. Bioresour Technol 2015;185:386-98. https://doi.org/10.1016/ j.biortech.2015.02.063.

[7] Ferraz Júnior ADN, Etchebehere C, Zaiat M. High organic loading rate on thermophilic hydrogen production and metagenomic study at an anaerobic packed-bed reactor treating a residual liquid stream of a Brazilian biorefinery. Bioresour Technol 2015;186:81-8. https://doi.org/10.1016/ j.biortech.2015.03.035.

[8] Peixoto G, Saavedra NK, Varesche MBA, Zaiat M. Hydrogen production from soft-drink wastewater in an upflow anaerobic packed-bed reactor. Int J Hydrogen Energy 2011;36:8953-66. https://doi.org/10.1016/ j.ijhydene.2011.05.014.

[9] Kumar G, Shobana S, Nagarajan D, Lee D-J, Lee K-S, Lin C-Y, et al. Biomass based hydrogen production by dark fermentation - recent trends and opportunities for greener processes. Curr Opin Biotechnol 2018;50:136-45. https:// doi.org/10.1016/j.copbio.2017.12.024.

[10] Rahman SNA, Masdar MS, Rosli MI, Majlan EH, Husaini T, Kamarudin SK, et al. Overview biohydrogen technologies and application in fuel cell technology. Renew Sustain Energy Rev 2016;66:137-62. https://doi.org/10.1016/ j.rser.2016.07.047. 
[11] Bakonyi P, Nemestóthy N, Simon V, Bélafi-Bakó K. Review on the start-up experiences of continuous fermentative hydrogen producing bioreactors. Renew Sustain Energy Rev 2014;40:806-13. https://doi.org/10.1016/j.rser.2014.08.014.

[12] Li Y, Qiren N, Chen Y, Xiangzheng G. Ecological mechanism of fermentative hydrogen production by bacteria. Int J Hydrogen Energy 2007;32:755-60. https://doi.org/10.1016/ j.ijhydene.2006.08.004.

[13] Ghimire A, Frunzo L, Pirozzi F, Trably E, Escudie R, Lens PNL, et al. A review on dark fermentative biohydrogen production from organic biomass: process parameters and use of byproducts. Appl Energy 2015;144:73-95. https://doi.org/ 10.1016/j.apenergy.2015.01.045.

[14] Chang J-S, Lee K-S, Lin P-J. Biohydrogen production with fixed-bed bioreactors. Int J Hydrogen Energy 2002;27:1167-74.

[15] Li C, Zhang T, Fang HHP. Fermentative hydrogen production in packed-bed and packing-free upflow reactors. Water Sci Technol 2006;54:95. https://doi.org/10.2166/wst.2006.712.

[16] Wu K-J, Chang C-F, Chang J-S. Simultaneous production of biohydrogen and bioethanol with fluidized-bed and packedbed bioreactors containing immobilized anaerobic sludge. Process Biochem 2007;42:1165-71. https://doi.org/10.1016/ j.procbio.2007.05.012.

[17] Lee K-S, Lo Y-S, Lo Y-C, Lin P-J, Chang J-SH. 2 production with anaerobic sludge using activated-carbon supported packedbed bioreactors. Biotechnol Lett 2003;25:133-8.

[18] Keskin T, Giusti L, Azbar N. Continuous biohydrogen production in immobilized biofilm system versus suspended cell culture. Int J Hydrogen Energy 2012;37:1418-24. https:// doi.org/10.1016/j.ijhydene.2011.10.013.

[19] Fontes Lima DM, Zaiat M. The influence of the degree of back-mixing on hydrogen production in an anaerobic fixedbed reactor. Int J Hydrogen Energy 2012;37:9630-5. https:// doi.org/10.1016/j.ijhydene.2012.03.097.

[20] Fontes Lima DM, Moreira WK, Zaiat M. Comparison of the use of sucrose and glucose as a substrate for hydrogen production in an upflow anaerobic fixed-bed reactor. Int $\mathrm{J}$ Hydrogen Energy 2013;38:15074-83. https://doi.org/10.1016/ j.ijhydene.2013.09.003.

[21] Penteado ED, Lazaro CZ, Sakamoto IK, Zaiat M. Influence of seed sludge and pretreatment method on hydrogen production in packed-bed anaerobic reactors. Int J Hydrogen Energy 2013;38:6137-45. https://doi.org/10.1016/ j.ijhydene.2013.01.067.

[22] Ferraz Júnior ADN, Zaiat M, Gupta M, Elbeshbishy E, Hafez H, Nakhla G. Impact of organic loading rate on biohydrogen production in an up-flow anaerobic packed bed reactor (UAnPBR). Bioresour Technol 2014;164:371-9. https://doi.org/ 10.1016/j.biortech.2014.05.011.

[23] Si B, Liu Z, Zhang Y, Li J, Xing X-H, Li B, et al. Effect of reaction mode on biohydrogen production and its microbial diversity. Int J Hydrogen Energy 2015;40:3191-200. https://doi.org/ 10.1016/j.ijhydene.2015.01.030.

[24] Si B, Li J, Li B, Zhu Z, Shen R, Zhang Y, et al. The role of hydraulic retention time on controlling methanogenesis and homoacetogenesis in biohydrogen production using upflow anaerobic sludge blanket (UASB) reactor and packed bed reactor (PBR). Int J Hydrogen Energy 2015;40:11414-21. https://doi.org/10.1016/j.ijhydene.2015.04.035.

[25] Wu S, Hung C, Lin C, Lin P, Lee K, Lin C, et al. HRT-dependent hydrogen production and bacterial community structure of mixed anaerobic microflora in suspended, granular and immobilized sludge systems using glucose as the carbon substrate. Int J Hydrogen Energy 2008;33:1542-9. https:// doi.org/10.1016/j.ijhydene.2007.10.020.

[26] Chiranjeevi P, Naresh Kumar A, Venkata Mohan S. Critical assessment of biofilm and suspended growth reactor configurations for acidogenic biohydrogen production using wastewater as a function of redox microenvironment. Int J Hydrogen Energy 2014;39:7561-71. https://doi.org/10.1016/ j.ijhydene.2014.02.040.

[27] dos Reis CM, Silva EL. Simultaneous coproduction of hydrogen and ethanol in anaerobic packed-bed reactors. BioMed Res Int 2014;2014:1-10. https://doi.org/10.1155/2014/ 921291.

[28] Sivagurunathan P, Anburajan P, Park J-H, Kumar G, Park H-D, Kim S-H. Mesophilic biogenic $\mathrm{H}_{2}$ production using galactose in a fixed bed reactor. Int J Hydrogen Energy 2017;42:3658-66. https://doi.org/10.1016/j.ijhydene.2016.07.203.

[29] Perna V, Castelló E, Wenzel J, Zampol C, Fontes Lima DM, Borzacconi L, et al. Hydrogen production in an upflow anaerobic packed bed reactor used to treat cheese whey. Int J Hydrogen Energy 2013;38:54-62. https://doi.org/10.1016/ j.ijhydene.2012.10.022.

[30] Castelló E, Braga L, Fuentes L, Etchebehere C. Possible causes for the instability in the $\mathrm{H}_{2}$ production from cheese whey in a CSTR. Int J Hydrogen Energy 2018;43:2654-65. https://doi.org/ 10.1016/j.ijhydene.2017.12.104.

[31] Arriaga S, Rosas I, Alatriste-Mondragón F, Razo-Flores E. Continuous production of hydrogen from oat straw hydrolysate in a biotrickling filter. Int J Hydrogen Energy 2011;36:3442-9. https://doi.org/10.1016/j.ijhydene.2010. 12.019.

[32] Laxman Pachapur V, Jyoti Sarma S, Kaur Brar S, Le Bihan Y, Ricardo Soccol C, Buelna G, et al. Co-culture strategies for increased biohydrogen production: strategies for increased biohydrogen production by co-culture system. Int J Energy Res 2015;39:1479-504. https://doi.org/10.1002/er.3364.

[33] Luo G, Karakashev D, Xie L, Zhou Q, Angelidaki I. Long-term effect of inoculum pretreatment on fermentative hydrogen production by repeated batch cultivations:

homoacetogenesis and methanogenesis as competitors to hydrogen production. Biotechnol Bioeng 2011;108:1816-27. https://doi.org/10.1002/bit.23122.

[34] O-Thong S, Prasertsan P, Birkeland N-K. Evaluation of methods for preparing hydrogen-producing seed inocula under thermophilic condition by process performance and microbial community analysis. Bioresour Technol 2009;100:909-18. https://doi.org/10.1016/j.biortech.2008 07.036.

[35] Hu B, Chen S. Pretreatment of methanogenic granules for immobilized hydrogen fermentation. Int J Hydrogen Energy 2007;32:3266-73. https://doi.org/10.1016/j.ijhydene.2007. 03.005.

[36] Lee M-J, Song J-H, Hwang S-J. Effects of acid pre-treatment on bio-hydrogen production and microbial communities during dark fermentation. Bioresour Technol 2009;100:1491-3. https://doi.org/10.1016/j.biortech.2008.08.019.

[37] Shi X-Y, Jin D-W, Sun Q-Y, Li W-W. Optimization of conditions for hydrogen production from brewery wastewater by anaerobic sludge using desirability function approach. Renew Energy 2010;35:1493-8. https://doi.org/ 10.1016/j.renene.2010.01.003.

[38] Elbeshbishy E, Hafez H, Dhar BR, Nakhla G. Single and combined effect of various pretreatment methods for biohydrogen production from food waste. Int J Hydrogen Energy 2011;36:11379-87. https://doi.org/10.1016/ j.ijhydene.2011.02.067.

[39] Jeong D-Y, Cho S-K, Shin H-S, Jung K-W. Application of an electric field for pretreatment of a seeding source for dark fermentative hydrogen production. Bioresour Technol 2013;139:393-6. https://doi.org/10.1016/j.biortech.2013. 04.039.

[40] $\mathrm{Mu} \mathrm{Y,} \mathrm{Yu} \mathrm{H-Q,} \mathrm{Wang} \mathrm{G.} \mathrm{Evaluation} \mathrm{of} \mathrm{three} \mathrm{methods} \mathrm{for}$ enriching H2-producing cultures from anaerobic sludge. 
Enzym Microb Technol 2007;40:947-53. https://doi.org/ 10.1016/j.enzmictec.2006.07.033.

[41] Ren N, Guo W, Wang X, Xiang W, Liu B, Wang X, et al. Effects of different pretreatment methods on fermentation types and dominant bacteria for hydrogen production. Int J Hydrogen Energy 2008;33:4318-24. https://doi.org/10.1016/ j.ijhydene.2008.06.003.

[42] Alemahdi N, Che Man H, Abd Rahman N, Nasirian N, Yang Y. Enhanced mesophilic bio-hydrogen production of raw rice straw and activated sewage sludge by co-digestion. Int J Hydrogen Energy 2015;40:16033-44. https://doi.org/10.1016/ j.ijhydene.2015.08.106.

[43] Lin C-N, Wu S-Y, Chang J-S, Chang J-S. Biohydrogen production in a three-phase fluidized bed bioreactor using sewage sludge immobilized by ethylene-vinyl acetate copolymer. Bioresour Technol 2009;100:3298-301. https:// doi.org/10.1016/j.biortech.2009.02.027.

[44] Vijaya Bhaskar Y, Venkata Mohan S, Sarma PN. Effect of substrate loading rate of chemical wastewater on fermentative biohydrogen production in biofilm configured sequencing batch reactor. Bioresour Technol 2008;99:6941-8. https://doi.org/10.1016/j.biortech.2008.01.029.

[45] Venkata Mohan S, Vijaya Bhaskar Y, Sarma PN. Biohydrogen production from chemical wastewater treatment in biofilm configured reactor operated in periodic discontinuous batch mode by selectively enriched anaerobic mixed consortia. Water Res 2007;41:2652-64. https://doi.org/10.1016/ j.watres.2007.02.015.

[46] Barros AR, Silva EL. Hydrogen and ethanol production in anaerobic fluidized bed reactors: performance evaluation for three support materials under different operating conditions. Biochem Eng J 2012;61:59-65. https://doi.org/ 10.1016/j.bej.2011.12.002.

[47] Shida GM, Sader LT, Cavalcante de Amorim EL, Sakamoto IK, Maintinguer SI, Saavedra NK, et al. Performance and composition of bacterial communities in anaerobic fluidized bed reactors for hydrogen production: effects of organic loading rate and alkalinity. Int J Hydrogen Energy 2012;37: 16925-34. https://doi.org/10.1016/j.ijhydene.2012.08.140.

[48] dos Reis CM, Silva EL. Effect of upflow velocity and hydraulic retention time in anaerobic fluidized-bed reactors used for hydrogen production. Chem Eng J 2011;172:28-36. https:// doi.org/10.1016/j.cej.2011.05.009.

[49] Karadag D, Köroğlu OE, Ozkaya B, Cakmakci M. A review on anaerobic biofilm reactors for the treatment of dairy industry wastewater. Process Biochem 2015;50:262-71. https:// doi.org/10.1016/j.procbio.2014.11.005.

[50] Infantes D, González del Campo A, Villaseñor J, Fernández FJ. Influence of $\mathrm{pH}$, temperature and volatile fatty acids on hydrogen production by acidogenic fermentation. Int $J$ Hydrogen Energy 2011;36:15595-601. https://doi.org/10.1016/ j.ijhydene.2011.09.061.

[51] Wang J, Wan W. Effect of temperature on fermentative hydrogen production by mixed cultures. Int J Hydrogen Energy 2008;33:5392-7. https://doi.org/10.1016/ j.ijhydene.2008.07.010.

[52] Beckers L, Masset J, Hamilton C, Delvigne F, Toye D, Crine M, et al. Investigation of the links between mass transfer conditions, dissolved hydrogen concentration and biohydrogen production by the pure strain Clostridium butyricum CWBI1009. Biochem Eng J 2015;98:18-28. https:// doi.org/10.1016/j.bej.2015.01.008.

[53] Shida GM, Barros AR, dos Reis CM, de Amorim ELC, Rissato Zamariolli Damianovic MH, Silva EL. Long-term stability of hydrogen and organic acids production in an anaerobic fluidized-bed reactor using heat treated anaerobic sludge inoculum. Int J Hydrogen Energy 2009;34:3679-88. https:// doi.org/10.1016/j.ijhydene.2009.02.076.
[54] Wang J, Wan W. Factors influencing fermentative hydrogen production: a review. Int J Hydrogen Energy 2009;34:799-811. https://doi.org/10.1016/j.ijhydene.2008.11.015.

[55] Kumar G, Mudhoo A, Sivagurunathan P, Nagarajan D, Ghimire A, Lay C-H, et al. Recent insights into the cell immobilization technology applied for dark fermentative hydrogen production. Bioresour Technol 2016;219:725-37. https://doi.org/10.1016/j.biortech.2016.08.065.

[56] Rachman MA, Furutani Y, Nakashimada Y, Kakizono T, Nishio N. Enhanced hydrogen production in altered mixed acid fermentation of glucose by Enterobacter aerogenes. J Ferment Bioeng 1997;83:358-63.

[57] Barton LE, Auffan M, Bertrand M, Barakat M, Santaella C, Masion A, et al. Transformation of pristine and citratefunctionalized $\mathrm{CeO}_{2}$ nanoparticles in a laboratory-scale activated sludge reactor. Environ Sci Technol 2014;48:7289-96. https://doi.org/10.1021/es404946y.

[58] Croese E, Pereira MA, Euverink G-JW, Stams AJM, Geelhoed JS. Analysis of the microbial community of the biocathode of a hydrogen-producing microbial electrolysis cell. Appl Microbiol Biotechnol 2011;92:1083-93. https:// doi.org/10.1007/s00253-011-3583-x.

[59] Goud RK, Mohan SV. Acidic and alkaline shock pretreatment to enrich acidogenic biohydrogen producing mixed culture: long term synergetic evaluation of microbial inventory, dehydrogenase activity and bio-electro kinetics. RSC Adv 2012;2:6336. https://doi.org/10.1039/c2ra20526b.

[60] Laothanachareon T, Kanchanasuta S, Mhuanthong W, Phalakornkule C, Pisutpaisal N, Champreda V. Analysis of microbial community adaptation in mesophilic hydrogen fermentation from food waste by tagged 16S rRNA gene pyrosequencing. J Environ Manage 2014;144:143-51. https:// doi.org/10.1016/j.jenvman.2014.05.019.

[61] Zhang K, Ren N, Guo C, Wang A, Cao G. Effects of various pretreatment methods on mixed microflora to enhance biohydrogen production from corn stover hydrolysate. J Environ Sci 2011;23:1929-36. https://doi.org/10.1016/S10010742(10)60679-1.

[62] Baghchehsaraee B, Nakhla G, Karamanev D, Margaritis A, Reid G. The effect of heat pretreatment temperature on fermentative hydrogen production using mixed cultures. Int J Hydrogen Energy 2008;33:4064-73. https://doi.org/10.1016/ j.jihydene.2008.05.069.

[63] El-Bery H, Tawfik A, Kumari S, Bux F. Effect of thermal pretreatment on inoculum sludge to enhance bio-hydrogen production from alkali hydrolysed rice straw in a mesophilic anaerobic baffled reactor. Environ Technol 2013;34:1965-72. https://doi.org/10.1080/09593330.2013.824013.

[64] APHA standard methods for the examination of water and waster water. 21st ed. Washington, DC: American Public Health Association; 2005.

[65] Hawkes F, Hussy I, Kyazze G, Dinsdale R, Hawkes D. Continuous dark fermentative hydrogen production by mesophilic microflora: principles and progress. Int J Hydrogen Energy 2007;32:172-84. https://doi.org/10.1016/ j.ijhydene.2006.08.014.

[66] Saady NMC. Homoacetogenesis during hydrogen production by mixed cultures dark fermentation: unresolved challenge. Int J Hydrogen Energy 2013;38:13172-91. https://doi.org/ 10.1016/j.ijhydene.2013.07.122.

[67] Oh S-E, Van Ginkel S, Logan BE. The relative effectiveness of $\mathrm{pH}$ control and heat treatment for enhancing biohydrogen gas production. Environ Sci Technol 2003;37:5186-90. https://doi.org/10.1021/es034291y.

[68] Duangmanee T, Padmasiri SI, Simmons JJ, Raskin L, Sung S. Hydrogen production by anaerobic microbial communities exposed to repeated heat treatments. Water Environ Res 2007;79:975-83. https://doi.org/10.2175/106143007X175762. 
[69] Zhu H, Parker W, Basnar R, Proracki A, Falletta P, Béland M, et al. Buffer requirements for enhanced hydrogen production in acidogenic digestion of food wastes. Bioresour Technol 2009;100:5097-102. https://doi.org/10.1016/j.biortech.2009. 02.066.

[70] Barca C, Ranava D, Bauzan M, Ferrasse J-H, GiudiciOrticoni M-T, Soric A. Fermentative hydrogen production in an up-flow anaerobic biofilm reactor inoculated with a coculture of Clostridium acetobutylicum and Desulfovibrio vulgaris. Bioresour Technol 2016;221:526-33. https:/doi.org/ 10.1016/j.biortech.2016.09.072. 